\title{
Ewa Ogrodzka-Mazur, Anna Szafrańska-Gajdzica, Barbara Grabowska, Lukasz Kwadrans: Education of children and youth in culturally diverse environments: experiences - problems - prospects Munich 2016, Lincom Academic Publishers, pp. 182
}

Praca autorstwa Ewy Ogrodzkiej-Mazur, Barbary Grabowskiej, Anny SzafrańskiejGajdzicy i Łukasza Kwadransa pt. Education of Children and Youth in Culturally Diverse Environments. Experience - Problems - Prospects stanowi drugi tom $\mathrm{z}$ serii Interculturalism and Intercultural Education wydawanej w Monachium przez LINCOM Academic Publishers. W publikacji, na podstawie wyników badań prowadzonych w ramach europejskiego projektu badawczego IRNet, zaprezentowano autorskie ujęcie problematyki rzeczywistości edukacyjnej dzieci i młodzieży w środowiskach zróżnicowanym kulturowo. Autorzy w jasny i przejrzysty sposób wskazują na potrzebę edukacji międzykulturowej, w sposób szczególny traktując aktualne problemy edukacji dzieci i młodzieży, ukazując je w społeczno-kulturowym kontekście. Jak słusznie zauważają we wstępie książki, „Polska nie należy do państw, w których wypracowane modele działań międzykulturowych są powszechnie realizowane", co bywa tłumaczone nikłą potrzebą z uwagi na niewielkie zróżnicowanie kulturowe kraju. Jednak potężne migracje ludności wywołują nasilanie się zjawiska zróżnicowania kulturowego również u nas. Otwarcie granic - coraz większa mobilność Polaków, możliwość obcowania z ludźmi reprezentującymi odmienne kultury - wskazuje na konieczność podejmowania w szkołach nowych zagadnień. Szkoła może być miejscem uczenia się otwartości, tolerancji, umiejętności poruszania się w świecie przenikających się kultur bądź miejscem nabywania stereotypów, doświadczania odrzucenia, uczenia się zachowań piętnujących Innych - sytuacja zależy od (nie)przyjęcia odpowiednich rozwiązań edukacyjnych i wychowawczych.

Publikacja składa się z czterech rozdziałów. W pierwszym rozdziale pt. School in borderlands - a laboratory for acquiring intercultural competences or/and stereotypes? stanowiącym niezbędne do dalszych rozważań tło i podstawę teoretyczną, Anna Szafrańska-Gajdzica zwraca uwagę na problematykę szkoły w przestrzeni wielokulturowej oraz działania edukacyjne nauczycieli w środowiskach zróżnicowanych kulturowo. Pytania sformułowane przez nią: Czy szkoły te są laboratorium budowania kompetencji międzykulturowych, czy/i nabywania stereotypów? Jaki jest obraz szkoły prezentowany przez uczniów (również w perspektywie pokoleniowej)? Jaki obraz szkoły mają aktualni uczniowie ze szkół średnich żyjący na pograniczu kulturowym i na ile jest podobny/różny od obrazu szkoły ich rówieśników sprzed 
25 lat? - są istotne z punktu widzenia współczesnych przemian społeczno-kulturowych oraz wynikających z nich nowych potrzeb edukacyjnych. Na uwagę zasługuje metodologiczne osadzenie rozważań autorki w teorii - odwołanie się do Jerome’a S. Brunera koncepcji szkoły jako kultury uczącej się oraz tezy o kulturze jako podstawowej orientacji współczesnej edukacji. Ostateczną konkluzją autorki, sformułowaną na podstawie wniosków z badań, jest wskazanie na potrzebę realizacji w szkołach edukacji międzykulturowej, sprzyjającej tworzeniu wielowymiarowego poczucia tożsamości dzieci i młodzieży oraz wzmacnianiu szans na radzenie sobie przez młode pokolenie ze światem, zarówno w szkole, jak i poza nią.

Rozdział drugi pt. The specificity of educating young learners in the culturally diversified environment wyszedł spod pióra Ewy Ogrodzkiej-Mazur, znawczyni problematyki wczesnoszkolnej pedagogiki międzykulturowej. Przedmiotem refleksji naukowej autorki są kategorie kulturowe i poznawcze, które można włączyć w zakres rozważań o kształtowaniu tożsamości pedagogiki wczesnoszkolnej oraz nowej jakości kształcenia zintegrowanego w niższych klasach szkoły podstawowej. Prezentuje zarys autorskiej koncepcji strategii wychowania międzykulturowego w edukacji wczesnoszkolnej. Wyróżnione płaszczyzny integracji: aksjopedagogiczna, kulturowa oraz metodyczno-organizacyjna uwzględniają trzy podstawowe warstwy określonych w ich obrębie strategii: teleologiczną, treściową oraz prakseologiczną (działaniową), umożliwiając zarazem konstruowanie sytuacji wychowawczych. W tych sytuacjach, podkreśla autorka, istotną rolę odgrywa nauczyciel, który musi być zdolny do budowania relacji z wychowankami, relacji warunkujących niezbędne doświadczenia uczniów oraz kształtowanie umiejętności komunikacji i kompetencji międzykulturowych. Budowanie relacji między ludźmi jest podstawą dyskursu międzykulturowego, którego głównym założeniem jest odejście od dwubiegunowości, od opozycji Ja/Obcy czy My/Oni, na rzecz wielobiegunowości wyznaczanej wartościowymi kontaktami i relacjami między jednostkami i grupami. Rozdział zawiera syntetyczne opracowanie tematyki tytułowej, która w takiej formie, co warto podkreślić, poruszana jest dość rzadko. Szczególnie istotne są końcowe konstatacje Ogrodzkiej-Mazur, w których podkreśla, że należy więcej uwagi poświęcić praktyce międzykulturowej, zwłaszcza postuluje konieczność zmiany kształcenia i dokształcania nauczycieli, gdyż osoby kształcące dzieci i młodzież powinny wykazywać się kompetencją międzykulturową.

Przedmiotem zainteresowania Barbary Grabowskiej w rozdziale pt. School education for national minorities in Poland and selected neighbouring countries jest funkcjonowanie szkolnictwa narodowościowego w Polsce oraz w krajach sąsiadujących - Białorusi, Republice Czeskiej i Ukrainie. Autorka przeprowadza tutaj analizę porównawczą w kontekście przemian społeczno-politycznych, które zaszły w ostatnich dziesięcioleciach zarówno w tych krajach, jak i w całej Europie. W przywołanych państwach mieszka polska mniejszość narodowa, a w Polsce żyją mniej- 
szości narodowe, których ojczyzny zagraniczne są naszymi sąsiadami. W sposób szczególny odnosi się autorka do prawnych aspektów funkcjonowania mniejszości narodowych, w tym ochrony praw jej członków w zakresie oświaty. Podkreśla, że czynnikiem różnicującym kwestie regulacji praw i ich przestrzegania - na poziomie poszczególnych krajów europejskich - jest system polityczny państw oraz praktyczne aspekty przestrzegania prawa, zwłaszcza w dziedzinie praw i wolności człowieka oraz wzajemnych odniesień grup narodowościowych wobec siebie. Autorka zwraca także uwagę na to, że szkoła mniejszościowa ma do spełnienia zadania i funkcje wyznaczone przez grupę mniejszościową, zadania oczekiwane przez społeczeństwo większościowe, a ponadto powinna być miejscem wzajemnego spotkania i dialogu kultur, miejscem kształtowania świadomości międzykulturowej, oznaczającej zdolność do dostrzegania i akceptowania wartości charakterystycznych dla innych kultur i społeczeństw. Cenna jest końcowa uwaga autorki, przywołująca konieczność prowadzenia edukacji międzykulturowej zarówno wśród członków grup mniejszościowych, jak i większościowych.

Publikację zamyka opracowanie Łukasza Kwadransa pt. A culturally different learner or a learner with special educational needs? Autor nakreślił w nim najważniejsze doświadczenia, problemy i perspektywy działalności edukacyjnej z dzieckiem odmiennym kulturowo i jego rodziną - jak w szkole, tak i poza nią. Poprzez odwołanie się do konkretnych problemów codziennego życia uczniów wskazał na specyfikę sytuacji edukacyjnej dzieci odmiennych kulturowo w Polsce i Europie, wynikającą z odmienności ich kultury, tradycji, norm zachowania i stylu życia. Przedstawił też wybrane problemy nauczycieli-wychowawców i wysunął ich możliwe praktyczne rozwiązania, podkreślając potrzebę wsparcia nauczyciela poprzez instytucję asystenta kulturowego i system edukacyjny. Rozdział ten zawiera również informacje dotyczące dostosowania wymagań szkolnych do możliwości uczniów odmiennych kulturowo, które są osobami dwukulturowymi i dwujęzycznymi i powinny być traktowane jako dzieci ze specyficznymi potrzebami edukacyjnymi. Reasumując, rozdział ten, podobnie jak poprzednie, dostarcza nie tylko wielu cennych informacji, ale też konkretnych propozycji zmian w obszarze praktyki edukacyjnej. Zwłaszcza cenne, bo wynikające z doświadczenia zawodowego autora, są wskazówki dla nauczycieli/ wychowawców pracujących z uczniami odmiennymi kulturowo.

Sądzę, że prezentowana publikacja w istotny sposób poszerza sposób widzenia i rozumienia współczesnej rzeczywistości edukacyjnej w środowisku zróżnicowanym kulturowo, zarówno w warstwie rozważań teoretycznych, dotyczących m.in. szkoły w przestrzeni międzykulturowej, mniejszości narodowych, dzieci odmiennych kulturowo, kształtowania tożsamości kulturowej, nabywania i rozwijania kompetencji międzykulturowych, jak i - co równie, a może bardziej ważne - w warstwie konkretnych rozwiązań i propozycji praktyki edukacyjnej. Badacze starają się nie tylko opisać zastaną sytuację, ale również analizują problemy i formułują propozycje zmian, 
co stanowi istotny atut opracowania. O ponadprzeciętnych walorach recenzowanej książki stanowią głównie: aktualność i ranga podjętej problematyki, skład zespołu autorskiego, tworzony przez osoby doświadczone wieloletnią aktywnością badawczą w obszarze edukacji międzykulturowej, poziom naukowy zaprezentowanych rozdziałów oraz spójność i zwartość publikacji. Uznanie budzi zarówno logiczna sekwencja rozważań, jak i interesująca i istotna treść poszczególnych tekstów. Jednym z atutów recenzowanej książki jest również charakter badań polegający na analizie porównawczej doświadczeń różnych krajów.

Z pełnym przekonaniem można pracę zarekomendować polskim i zagranicznym czytelnikom zainteresowanym przedstawioną problematyką. Należy docenić fakt, że trafiła na zagraniczny rynek wydawniczy, gdzie z pewnością wzbudzi zainteresowanie zarówno pedagogów, jak i przedstawicieli innych nauk społecznych i humanistycznych oraz szerokiego grona praktyków, pracowników edukacji i oświaty.

Aniela Różańska 